\title{
Pengembangan Media Pembelajaran Berbasis Augmented Reality Pada Lembar Kerja Siswa Kelas 3 Madrasah Ibtidaiyah
}

\author{
Development Augmented Reality for Learning Media Based on Thrid Grade in Student \\ Worksheets at Madrasah Ibtidaiyah \\ Rafika Akhsani*1, M. Mujiono ${ }^{2}$ \\ ${ }^{1}$ Penyuntingan Audio dan Video, ${ }^{2}$ Administrasi Server dan Jaringan Komputer; Akademi \\ Komunitas Negeri Putra Sang Fajar Blitar \\ ${ }_{1,2}$ Blitar, Indonesia \\ e-mail: *11achsany@akb.ac.id, ${ }^{2}$ jono@akb.ac.id
}

\begin{abstract}
Abstrak - Media pembelajaran diperlukan bagi keberhasilan proses pembelajaran, khususnya bagi siswa yang masih duduk di Sekolah Dasar. Kerjasama antara guru dan orang tua merupakan kunci dari keberhasilan pembelajaran, khususnya pada musim pandemi Covid-19 yang mewajibkan siswa belajar dirumah. Berakibat pola pembelajaran yang biasanya tatap muka menjadi pembelajaran yang difasilitasi teknologi, salah satunya adalah dengan menggunakan smartphone. Salah satu teknologi yang dapat menjadi pendukung pembelajaran adalah dengan menggunakan teknologi Augmented Reality yang akan di integtasikan dengan smarthphone. Media yang akan dibuat memanfaatkan materi pada Lembar kerja siswa kelas tiga sekolah dasar yang dikemas dalam marker yang didesain dengan ukuran $4 x 4 \mathrm{~cm}$ kemudian dimasukkan ke dalam image target di Unity $3 D$ dan diberi nama AReP. Pengujian AReP menggunakan tiga cara yaitu oklusi, akurasi dan usabilitas. Dalam pengujian oklusi yang menggunakan kamera realme 5i menghasilkan kesimpulan AreP dapat mendeteksi marker sampai 70\%, tetapi pada marker yang tertutup lebih dari $80 \%$ animasi tidak muncul. Pengujian akurasi digunakan untuk melihat akurasi pendeteksian kamera augmented reality berdasarkan pada sudut dan jarak tertentu, yang menghasilkan jarak kesimpulan bahwa AReP bekerja dengan baik dengan maksimal jarak 30cm dan ketika jarak lebih dari $40 \mathrm{~cm}$ maka animasi tidak muncul. Pengujian usabilitas digunakan untuk mengetahui umpan balik dari pengguna media pembelajaran, hasil dari uji usabilitas menunjukkan bahwa 93\% responden menyetujui bahwa AReP dapat membantu anak dalam pembelajaran.
\end{abstract}

Kata kunci - komponen ; Augmented Reality, android, media pembelajaran, sekolah dasar, Madrasah Ibtidaiyah

\begin{abstract}
Learning media is needed for the success of the learning process, especially for students who are still in elementary school. Collaboration between teachers and parents is the key to successful learning, especially during the Covid-19 pandemic season, which requires students to study at home. Has the effect of changing learning from face-to-face to technology-facilitated learning, one of which is using a smartphone. One example of technology that can support learning is to use Augmented Reality which will be integrated with a smartphone. The media that will be created utilizes the material on the third grade elementary school student worksheets which are packaged in a marker designed with a size of $4 \times 4 \mathrm{~cm}$ then put into the target image in Unity $3 D$ and named AReP. AReP testing uses three tests that is occlusion, accuracy and usability. In occlusion testing using a camera realme 5i resulting in a conclusion AreP can detect up to $70 \%$ marker, but on a closed marker more than $80 \%$ animation does not appear. Accuracy testing is used to see the detection accuracy of an augmented reality camera based on a certain angle and distance, which results in a conclusion that AReP works well with a maximum distance of $30 \mathrm{~cm}$ and when the distance is more than $40 \mathrm{~cm}$ then the animation does not appear. Usability testing is used to find out feedback from users of learning media, the results of the usability test show that 93\% of respondents agree that AReP can help children in learning.
\end{abstract}

Keywords - Component ; Augmented Reality, android, learning media, elementery school, Madrasah Ibtidaiyah

\section{PEndahuluan}

Dunia anak-anak memang memang cenderung dengan dunia bermain. Seorang guru dituntut untuk selalu berinovasi dalam proses pembelajaran sehingga peserta didik mendapatkan pemahaman dan kenyamanan dalam belajar. Sesampai di rumah, siswa - siswi biasanya mempelajari lagi apa yang diajarkan oleh gurunya. Jika mereka lupa, mereka akan 
bertanya kepada orang tuanya. Orang tua terkadang tidak mengetahui apa yang ditanyakan oleh anaknya tentang pelajaran sekolah. Suatu misal adalah pada lembar kerja siswa (LKS) terdapat pelajaran tentang bernyanyi. Anak-anak sudah diajari gurunya di sekolah. Ketika sampai rumah mereka lupa seperti apa lagu yang diajarkan kepadanya tadi. Selain itu, terdapat juga pelajaran tentang berhitung. Anak-anak perlu mempelari berulang-ulang belajar tentang bagaimana cara mengerjakan soal pelajaran seperti itu supaya mereka dapat memahami cara penyeleseiannya.

Belajar membutuhkan sebuah proses. Proses dalam belajar bermacam-macam caranya. Perkembangan teknologi yang begitu pesat, muncul beberapa alternatif cara untuk membantu siswa sekolah untuk lebih memahami pelajaran di sekolah baik secara offline maupun online. Secara offline, ada sebagian siswa sekolah yang memilih lembaga bimbingan belajar sebagai alternatif tempat belajar tambahannya. Sedangkan secara online, saat ini banyak situs-situs yang menyediakan layanan bimbingan belajar berbasis video. Layanan ini menjadikan bimbingan belajar ini menjadi lebih mudah, yaitu dengan belajar secara online. Dengan cara ini siswa - siswi tidak perlu repot-repot lagi ke mana - mana sehingga cukup di rumah dan di depan layar Handphonel smartphone atau laptop yang terkoneksi dengan internet.

Seiring dengan adaya wabah pandemic corona di kabupaten Blitar yang berada di zona merah [1], maka siswa siswi sekolah harus belajar dari rumah [2]. Momentum ini dapat kita sikapi dengan memanfaatkan perkembangan teknologi untuk mencerdaskan anak bangsa meskipun terdapat musibah corona.

Saat ini, hampir semua orang tua siswa siswi sekolah sudah memiliki smartphone. Mestinya, hal ini dapat dimanfaatkan orang tua untuk mendukung proses belajar anaknya. Aplikasi yang dikembangkan dengan mobile dapat membantu proses pembelajaran [3] [4]. Akan tetapi, tidak sedikit pula generasi anak sekarang yang meminjam smartphone orang tuanya untuk bermain game. Bahkan banyak orang tua mengalami kesulitan dalam mencegah anak bermain smartphone dalam waktu yang lama.

Perkembangan teknologi dapat diintegrasikan untuk optimalisasi pembelajaran pada dunia Pendidikan. Salah satunya adalah teknologi
Augmented reality. Augmented reality merupakan teknologi yang mengkolaborasikan benda maya dua atau tiga dimensi dengan lingkungan nyata kemudian memproyeksikan objek-objek maya tersebut secara realitas dalam waktu nyata [5]. Augmented reality dapat digunakan sebagai media informasi dan komunikasi yang mudah dan daya jangkau luas[6].

Penelitian ini bertujuan untuk mengembangkan sebuah media pembelajaran yang menarik dan efisien menggunakan Augmented Reality dengan memanfaatkan fitur kamera Smartphone Android. Hal ini diharapkan dapat menjadi solusi untuk meningkatkan pemahaman siswa terhadap materi di sekolah tanpa harus memiliki koneksi internet sehingga orang tua siswa juga terbantu dengan adanya pengembangan aplikasi ini. Pengembangan aplikasi dilakukan dengan memanfaatkan aplikasi Unity dan EasyAR dalam membuat aplikasi pembelajaran untuk kelas 3 MI Hidayatul Ulum Blitar.

\section{LANDASAN TEORI}

\section{A. Media pembelajaran}

Media merupakan semua bentuk perantara yang digunakan oleh manusia untuk menyebarkan atau menyampaikan ide sehingga penerima dapat menerima informasi [7]. Jika informasi yang disampaikan mengandung maksud-maksud pengajaran, maka disebut dengan media pembelajaran. Secara umum, manfaat media pembelajaran adalah untuk membantu siswa belajar secara optimal dan mempermudah interaksi pendidik dengan siswa sehingga tujuan belajar tercapai. Adapun fungsi media pembelajaran adalah sebagai alat bantu mewujudkan situasi belajar yang efektif dan meletakkan dasar-dasar yang konkret dari konsep yang abstrak sehingga dapat mengurangi pemahaman yang bersifat verbalisme serta membangkitkan motivasi belajar peserta didik [8].

\section{B. Augmented Reality}

Augmented Reality atau yang sering disingkat dengan AR merupakan teknologi yang menggabungkan benda maya baik 2 dimensi atau 3 dimensi ke dalam sebuah lingkungan nyata 3 dimensi lalu memproyeksikan benda-benda maya tersebut 
dalam waktu nyata (Realtime) [9]. Hal ini sesuai sebagai alat untuk membantu presepsi dan interaksi penggunanya dengan dunia nyata. Augmented Reality adalah variasi dari sebuah lingkungan virtual yang membuat penggunanya dapat melihat dunia nyata yang telah digabungkan dengan objek virtual di dalamnya [10].

Saat ini, Augmented Reality dapat ditemukan pada media sosial seperti Instagram. Pada fitur story di Instagram, Anda dapat melakukan selfie dengan berbagai macam bingkai atau disebut filter. Ketika Anda menggunakan fitur filter ini, wajah Anda tidak berubah sama sekali di dunia nyata, akan tetapi wajah kita berubah di layar smartphone. Itulah teknologi augmented reality, sebuah teknologi yang berhubungan dengan dunia nyata.

Beberapa komponen yang diperlukan untuk membuat seluruh proses kerja serta berbagai jenis platform pada augmented reality [10] adalah Sebuah computer (PC ataupun Mobile), Monitor, Kamera, GPS, Kompas, dan sistem penginderaan, Infrastruktur jaringan, marker.

\section{Lembar Kerja Siswa}

Lembar Kerja Siswa atau LKS ialah lembaran yang berisi tugas yang harus dikerjakan oleh peserta didik atau siswa. LKS biasanya berupa petunjuk, langkah untuk menyelesaikan suatu tugas. Suatu tugas yang diperintahkan dalam lembar kegiatan harus jelas kompetensi dasar yang akan dicapainya [11]. Adapun tujuan dari LKS adalah:

- Mengaktifkan siswa dalam proses kegiatan pembelajaran.

- Membantu siswa mengembangkan konsep.

- Melatih siswa untuk menemukan dan mengembangkan ketrampilan proses.

- Sebagai pedoman guru dan siswa dalam melaksanakan proses kegiatan pembelajaran.

- Membantu siswa dalam memperoleh informasi tentang konsep yang dipelajari melalui proses kegiatan pembelajaran secara sistematis.

- Membantu siswa dalam memperoleh catatan materi yang dipelajari melalui kegiatan pembelajaran

D. EasyAR

Menurut laman resmi EasyAR (www.easyar.com), EasyAR SDK adalah Engine untuk pengembangan Augmented
Reality. Ada dua versi, yaitu EasyAR SDK Basic dan EasyAR SDK Pro. EasyAR merupakan SDK untuk membantu pengembang dalam menciptakan aplikasi atau game yang memiliki teknologi Augmented Reality. Untuk sebuah aplikasi maupun game yang dibuat dengan teknologi ini akan terlihat lebih interaktif dan hidup. Contohnya saja ketika pembaca mendapatkan sebuah penanda yang hanya berupa kertas dan secara tiba-tiba akan muncul objek virtual 3 dimensi ketika ponsel pintar atau tablet diarahkan ke kertas penanda tersebut.

Beberapa hal yang perlu disiapkan sebelum membuat Augmented Reality dengan EasyAR yaitu : SDK EasyAR, Unity3D, Android SDK, JDK 8.

\section{E. Unity $3 D$}

Unity merupakan sebuah game engine yang dibuat oleh Unity Technology. Yaitu sebuah software pengolah gambar, grafik, suara, input dan lain-lain yang ditujukan untuk membuat game. Unity 3D merupakan game engine multiplatform yang mampu di-publish (.exe), berbasis web, android, iOs, XBOX, maupun PS3, dengan catatan mendapatkan lisensi. Versi gratis hanya dapat di-publish ke dalam bentuk standalone dan web. Unity telah mendukung pengolahan graphic engine, seperti Direct $3 D$ (Windows, Xbox 360), OpenGL (Mac, Windows, Linux, PS3), OpenGL ED (Android, iOs), dan APIs (Wii). Scripting yang digunakan pada Unity3D dibangun menggunakan Mono 2.6 yang merupakan implementasi terbuka dari .NET Framework. Bahasa pemrograman yang didukung oleh Unity3D, antara lain Javascript, C\#, dan Boo (menggunakan sintaks Phyton). Mulai dari Unity3D versi 3.0, digunakan MonoDevelop untuk debugging script [12].

\section{METODE}

Metode yang digunakan pada penelitian ini adalah dengan menggunakan metode Multimedia Development Life Cycle (MDLC). MDLC memiliki 6 tahapan yaitu concept, design, material collecting, assembly, testing, dan distribution [13]. Diagram MDLC dapat dilihat pada gambar 1. 


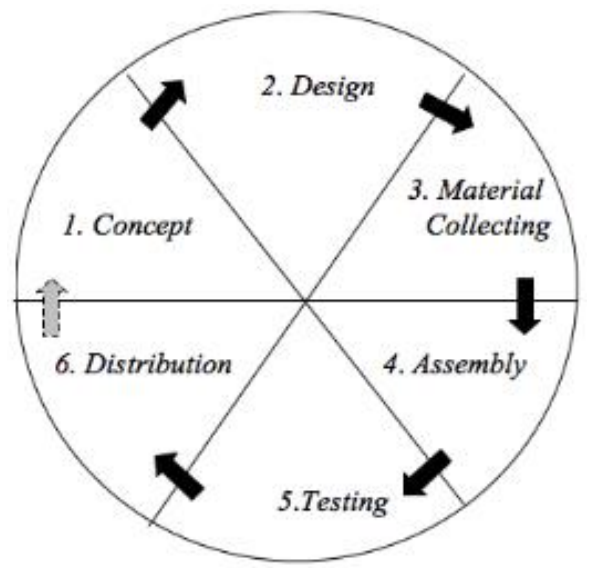

Gambar 1. Diagram MDLC

Penjabaran dari kegiatan yang dilakukan oleh peneliti pada setiap tahapan MDLC adalah sebagai berikut:

\section{a. Concept}

Aplikasi ini dikembangkan dengan menggunakan teknologi augmented reality dan berjalan di sistem operasi android. Spesifikasi smartphone android yang digunakan atau yang dapat diinstal aplikasi ini adalah smartphone yang menggunakan operating system android minimal versi android 4 ke atas.

Aplikasi ini menyajikan materi pembelajaran siswa kelas 3 MI yang dikemas dalam bentuk bahan ajar multimedia yang menarik sehingga dapat menambah wawasan dan semangat belajar para siswa. Materi yang ditampilkan berupa video yang disesuaikan topik yang telah ditentukan. Jadi dengan adanya aplikasi ini, diharapkan siswa dan orang tua akan terbantu ketika belajar secara mandiri di rumah meskipun tidak ada paket internet atau aplikasi ini dapat dijalankan tanpa adanya koneksi internet.

Aplikasi dibuat secara simple yang mana nantinya tidak akan merepotkan pengguna. Pada saat aplikasi dijalankan nantinya akan muncul splashscreen dan kemudian akan memunculkan menu. User selanjutnya tinggal pilih menu mulai belajar dan mengarahkan kamera pada buku tematik. Lalu aplikasi akan menampilkan materi/ konten sesuai gambar yang dikehendaki.

\section{b. Design}

Pada tahap ini dilakukan perancangan aplikasi dengan menggunakan usecase dan activity diagram. Usecase untuk aplikasi ini adalah seperti pada Gambar 2.

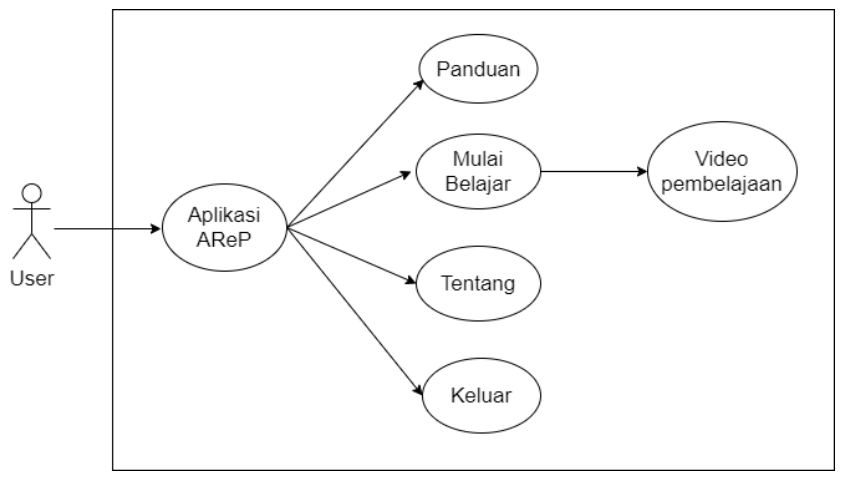

Gambar 2. Usecase aplikasi

Activity diagram untuk aplikasi ini seperti pada Gambar 3.

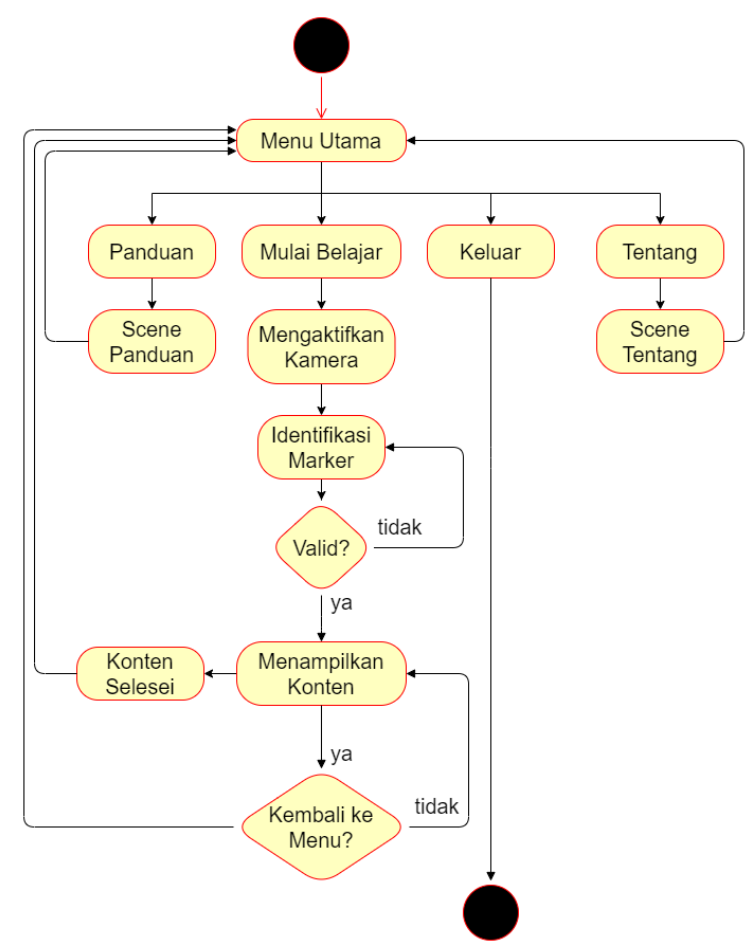

Gambar 3. Activity diagram aplikasi

\section{c. Material Collecting}

Pada tahap ini, peneliti akan melakukan wawancara kepada guru kelas serta membaca buku dan mencari sumber-sumber lainnya dari internet untuk mendapatkan materi terkait bahan ajar/ materi pembelajaran. Sedangkan untuk materi terkait Augmented Reality, peneliti mendapatkan materi dari buku referensi, internet dan tanya jawab dengan orang yang lebih ahli.

\section{d. Assembly}

Tahap assembly atau tahap pembuatan merupakan tahap dimana semua objek atau bahan multimedia dibuat. Pembuatan aplikasi didasarkan pada activity diagram. Semua objek atau material yang telah dibuat nantinya akan digabungkan menjadi satu aplikasi yang utuh. 
Dalam tahapan ini digunakan beberapa software seperti, Unity 3D, EasyAR, Software Editing Video, scanner, dan lainnya yang relevan dengan kebutuhan penelitian ini.

\section{e. Testing}

Testing merupakan sebuah tahapan untuk melakukan pengujian alpha (alpha test). Pengujian alpha dilakukan oleh pembuat atau lingkungan pembuatnya sendiri. Pada pengujian aplikasi dilakukan pengecekan apakah semua menu berjalan sesuai yang direncanakan dan ketepatan benda berdasarkan marker. Selanjutnya dilakukan pengujian terhadap ketersediaan benda/ obyek yang ingin ditampilkan sesuai marker. Pengujian selanjutnya dengan menggunakan pengujian kuisioner dengan responden siswa sekolah atau wali murid.

\section{f. Distribution}

Pada tahapan ini, aplikasi yang telah selesai di uji dan dinyatakan baik sesuai dengan tujuan pembuatan akan didistribusikan dengan cara menyebarkan informasi ke paguyuban wali murid siswa.

\section{HASIL DAN PEMBAHASAN}

\section{A. Gambaran umum aplikasi}

Aplikasi yang telah dibuat diberikan nama AReP. AReP merupakan merupakan kepanjangan dari Augmented Reality Pembelajaran. AReP merupakan media pembelajaran yang menarik yang dikembangkan dengan memanfaatkan fitur kamera Smartphone Android. AReP dikembangkan dengan menggunakan Unity 3D dan EasyAR. Aplikasi AReP menggunakan marker sebagai penanda (marker based augmented reality). Marker digunakan sebagai penanda untuk mengatur video atau animasi pembelajaran mana yang akan dimunculkan supaya sesuai dengan keinginan dari user atau pengguna aplikasi. Marker yang didesain dengan ukuran 4 x $4 \mathrm{~cm}$ kemudian dimasukkan ke dalam image target di Unity 3D.

Marker yang telah dibuat kemudian dicetak seperti stiker dan ditempelkan pada buku lembar kerja siswa. Hal ini dilakukan karena buku lembar kerja siswa menggunakan kertas buram yang mana setelah dilakukan ujicoba beberapa kali marker tidak dikenali.

\section{B. Hasil dan pembahasan}

Pada saat aplikasi AReP dijalankan, aplikasi akan menampilkan splashscreen seperti pada Gambar 4 selama 3 detik dan selanjutnya menampilkan menu utama yang dapat dilihat pada Gambar 5.

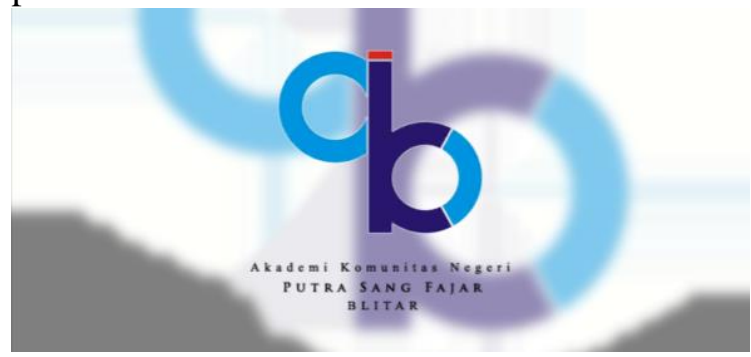

Gambar 4. Antar muka splashscreen AReP

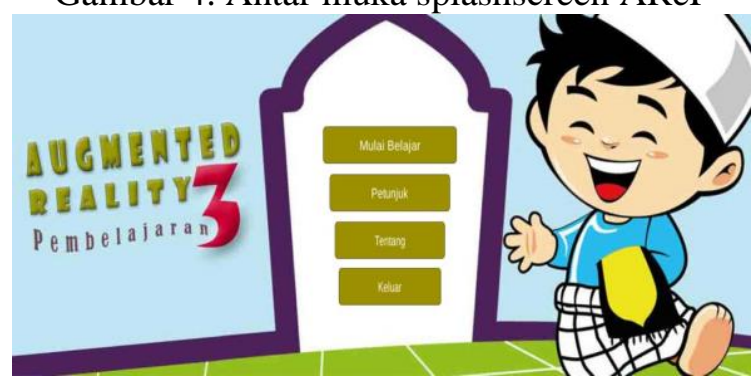

Gambar 5. Antar muka menu utama aplikasi AReP

Aplikasi AReP memiliki 4 menu yaitu mulai belajar, petunjuk, tentang, dan keluar. Menu petunjuk berisi tentang petunjuk penggunaan aplikasi AReP. Antar muka menu petunjuk dapat dilihat pada Gambar 6. Menu tentang berisi tentang tim pengembang aplikasi AReP. Antar muka menu tentang dapat dilihat pada Gambar 7. Menu keluar digunakan untuk keluar dari aplikasi. Menu mulai belajar merupakan inti dari aplikasi AReP ini. Adapun beberapa tampilan antar muka dari menu belajar dapat dilihat pada Gambar 8 sampai dengan Gambar 10.

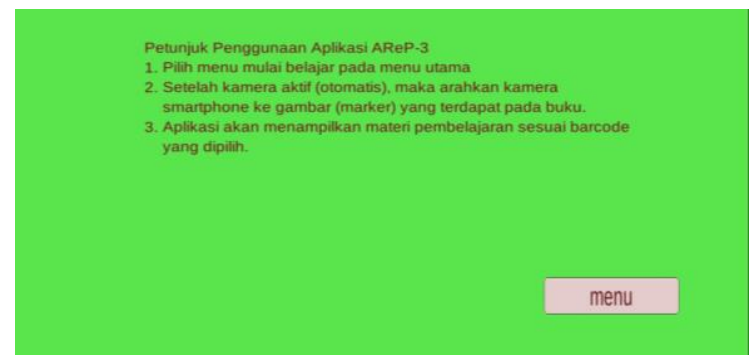

Gambar 6. Antar muka menu petunjuk 


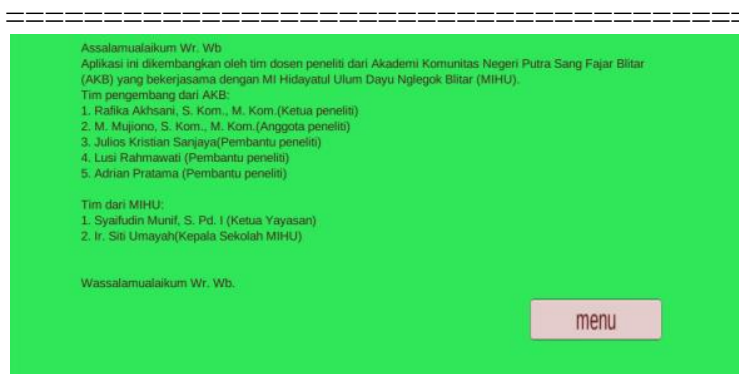

Gambar 7. Antar muka menu tentang

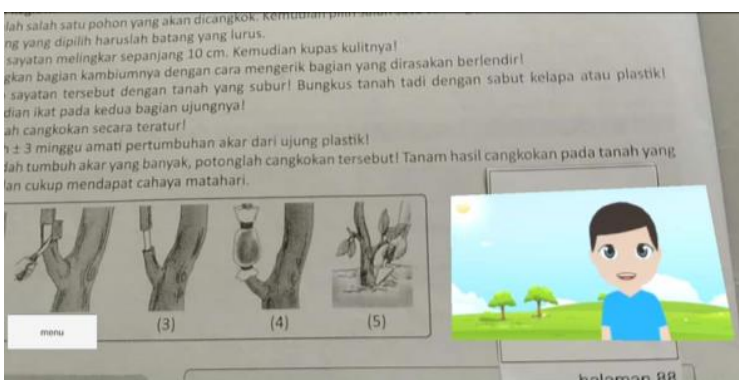

Gambar 8. Antar muka menu belajar hal 88

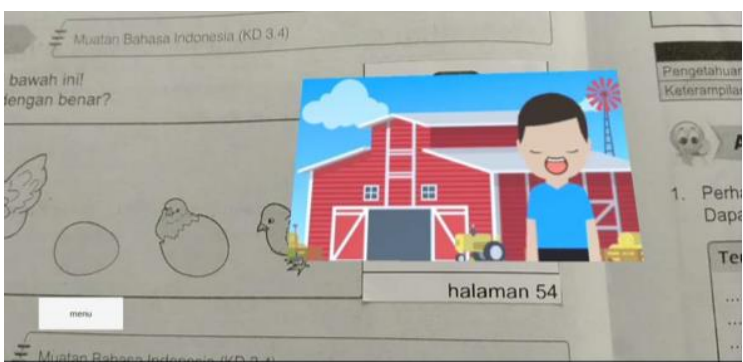

Gambar 9. Antar muka menu belajar hal 54

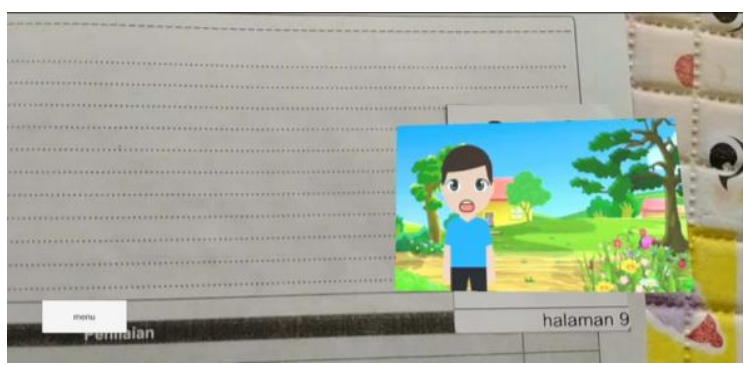

Gambar 10. Antar muka menu belajar hal 88

Pengujian aplikasi AReP dilakukan dengan 3 cara yaitu pengujian oklusi, pengujian akurasi, dan pengujian usabilitas. Pengujian oklusi merupakan cara menguji aplikasi yang didasarkan dari kejelasan marker [14]. Pengujian dilakukan dengan cara menutup sebagian marker. Hal ini dilakukan untuk mengetahui apakah marker tetap teridentifikasi oleh kamera jika kondisi marker terhalangi atau kondisi marker yang abnormal. Pada pengujian ini aplikasi diinstal pada smartphone realme $5 \mathrm{i}$ kemudian dilakukan penutupan marker 10 $100 \%$. Hasil dari pengujian oklusi yang dilakukan oleh peneliti dapat dilihat pada Tabel 1 .

Tabel 1. Pengujian oklusi

\begin{tabular}{ccccccc}
\hline $\begin{array}{c}\text { Area marker yang } \\
\text { terhalang }\end{array}$ & \multicolumn{6}{c}{ Marker yang diuji } \\
\cline { 2 - 6 } & $\mathbf{1}$ & $\mathbf{2}$ & $\mathbf{3}$ & $\mathbf{4}$ & $\mathbf{5}$ & $\mathbf{6}$ \\
\hline $10 \%$ & ya & ya & ya & ya & ya & ya \\
\hline $20 \%$ & ya & ya & ya & ya & ya & ya \\
\hline $30 \%$ & ya & ya & ya & ya & ya & ya \\
\hline $40 \%$ & ya & ya & ya & ya & ya & ya \\
\hline $50 \%$ & ya & ya & ya & ya & ya & ya \\
\hline $60 \%$ & ya & ya & ya & ya & ya & ya \\
\hline $70 \%$ & ya & ya & ya & ya & ya & ya \\
\hline $80 \%$ & tdk & tdk & tdk & tdk & tdk & tdk \\
\hline $90 \%$ & tdk & tdk & tdk & tdk & tdk & tdk \\
\hline $100 \%$ & tdk & tdk & tdk & tdk & tdk & tdk \\
\hline
\end{tabular}

Berdasarkan hasil pengujian oklusi marker pada Tabel 1, kamera augmented reality yang dijalankan pada smartphone realme $5 \mathrm{i}$ dapat mendeteksi marker sampai dengan $70 \%$ dan menampilkan objek yang relevan. Akan tetapi, ketika area marker tertutup sekitar $80-100 \%$ maka aplikasi tidak dapat menampilkan animasi.

Selanjutnya dilakukan pengujian akurasi. Pengujian akurasi adalah cara pengujian ketepatan pendeteksian kamera augmented reality berdasarkan pada sudut dan jarak tertentu. Hasil dari pengujian akurasi dapat dilihat pada Tabel 2 .

Tabel 2. Pengujian akurasi

\begin{tabular}{|c|c|c|c|c|c|c|c|}
\hline \multirow{2}{*}{$\begin{array}{l}\text { Jarak } \\
(\mathrm{cm})\end{array}$} & \multirow{2}{*}{$\begin{array}{c}\text { Sudut } \\
\text { (derajat) }\end{array}$} & \multicolumn{6}{|c|}{ Marker yang diuji } \\
\hline & & 1 & 2 & 3 & 4 & 5 & 6 \\
\hline \multirow{4}{*}{10} & 30 & ya & ya & ya & ya & ya & ya \\
\hline & 45 & ya & ya & ya & ya & ya & ya \\
\hline & 60 & ya & ya & ya & ya & ya & ya \\
\hline & 90 & ya & ya & ya & ya & ya & ya \\
\hline \multirow{4}{*}{20} & 30 & tdk & tdk & tdk & tdk & tdk & $\mathrm{tdk}$ \\
\hline & 45 & ya & ya & ya & ya & ya & ya \\
\hline & 60 & ya & ya & ya & ya & ya & ya \\
\hline & 90 & ya & ya & ya & ya & ya & ya \\
\hline \multirow{4}{*}{30} & 30 & $\mathrm{tdk}$ & $\mathrm{tdk}$ & $\mathrm{tdk}$ & $\mathrm{tdk}$ & $\mathrm{tdk}$ & $\mathrm{tdk}$ \\
\hline & 45 & ya & ya & ya & ya & ya & ya \\
\hline & 60 & ya & ya & ya & ya & ya & ya \\
\hline & 90 & ya & ya & ya & ya & ya & ya \\
\hline \multirow{4}{*}{40} & 30 & $\mathrm{tdk}$ & $\mathrm{tdk}$ & $\mathrm{tdk}$ & $\mathrm{tdk}$ & tdk & $\mathrm{tdk}$ \\
\hline & 45 & $\mathrm{tdk}$ & $\mathrm{tdk}$ & $\mathrm{tdk}$ & $\mathrm{tdk}$ & tdk & $\mathrm{tdk}$ \\
\hline & 60 & $\mathrm{tdk}$ & $\mathrm{tdk}$ & $\mathrm{tdk}$ & $\mathrm{tdk}$ & tdk & $\mathrm{tdk}$ \\
\hline & 90 & $\mathrm{tdk}$ & tdk & $\mathrm{tdk}$ & tdk & tdk & $\mathrm{tdk}$ \\
\hline
\end{tabular}

Hasil pengujian akurasi seperti disajikan pada Tabel 2, kita dapat mengetahui bahwa AReP dapat menampilkan animasi/ konten pada jarak maksimal $30 \mathrm{~cm}$. Ketika jarak lebih dari $40 \mathrm{~cm}$ maka aplikasi tidak dapat menampilkan konten.

Tahap pengujian yang terakhir adalah pengujian usabilitas. Pengujian usabilitas dilakukan untuk mengetahui umpan balik dari 
pengguna apakah aplikasi yang dibangun sudah kompatibel dengan kebutuhan dan preferensi pengguna yang dituju [15]. Pengujian usabilitas dilakukan dengan cara menyebarkan kuesioner kepada 30 responden. Responden penelitian adalah wali siswa dan siswa itu sendiri. Proses uji coba aplikasi yang dilakukan oleh siswa dapat dilihat pada Gambar 11. Sedangkan uji coba aplikasi yang dilakukan oleh wali siswa dapat dilihat pada Gambar 12.

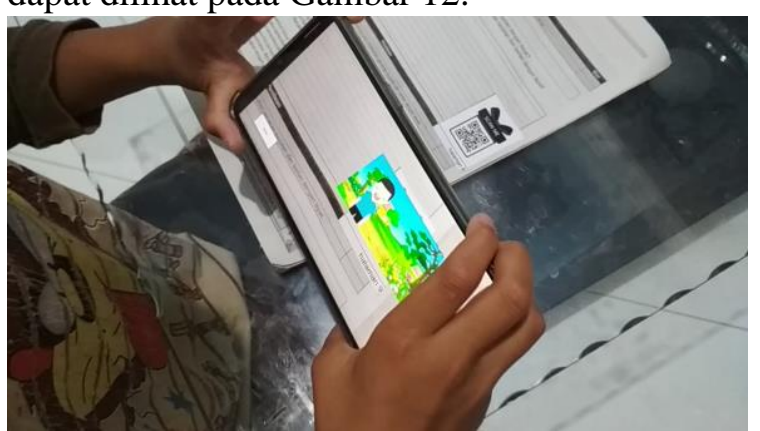

Gambar 11. Uji coba oleh siswa

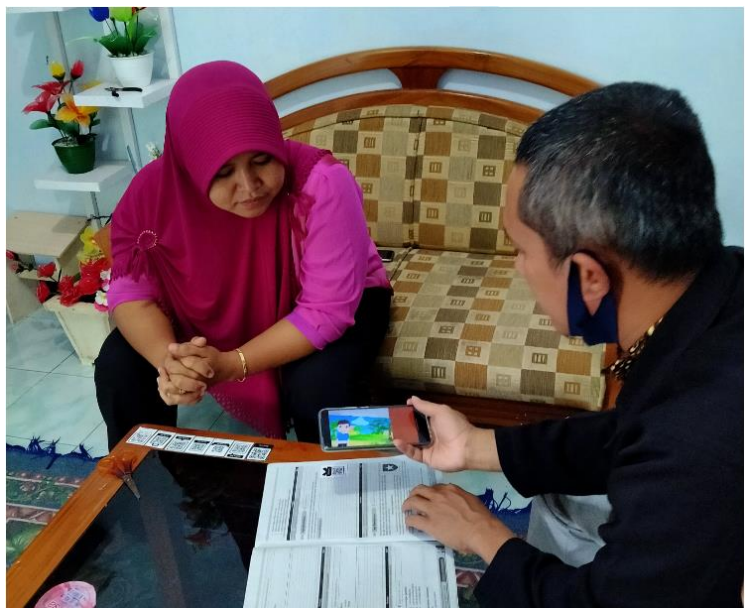

Gambar 12. Uji coba oleh wali siswa

Pertanyaan pada kuesioner dibuat menjadi 2 segmen yaitu pertanyaan yang diisi oleh wali siswa (Tabel 3) dan pertanyaan yang diisi siswa (Tabel 4).

Tabel 3. Hasil jawaban responden wali siswa

\begin{tabular}{|c|c|c|c|c|c|}
\hline \multirow[b]{2}{*}{ No } & \multirow[b]{2}{*}{ Pernyataan } & \multicolumn{4}{|c|}{ Jawaban Responden } \\
\hline & & $\begin{array}{l}\text { Sangat } \\
\text { Tidak } \\
\text { setuju }\end{array}$ & $\begin{array}{l}\text { Tidak } \\
\text { setuju }\end{array}$ & setuju & $\begin{array}{l}\text { Sangat } \\
\text { Setuju }\end{array}$ \\
\hline 1. & $\begin{array}{l}\text { Aplikasi Media } \\
\text { Pembelajaran } \\
\text { Berbasis } \\
\text { Augmented } \\
\text { Reality ini } \\
\text { untuk mudah } \\
\text { digunakan }\end{array}$ & 0 & $3,33 \%$ & $\begin{array}{c}13,33 \\
\%\end{array}$ & $\begin{array}{c}83,33 \\
\%\end{array}$ \\
\hline 2. & $\begin{array}{l}\text { Animasi dalam } \\
\text { aplikasi ini } \\
\text { berjalan dengan } \\
\text { baik. }\end{array}$ & 0 & $0,00 \%$ & $\begin{array}{c}33,33 \\
\%\end{array}$ & $\begin{array}{c}66,67 \\
\%\end{array}$ \\
\hline
\end{tabular}

\begin{tabular}{|c|c|c|c|c|c|}
\hline \multirow[b]{2}{*}{ No } & \multirow[b]{2}{*}{ Pernyataan } & \multicolumn{4}{|c|}{ Jawaban Responden } \\
\hline & & $\begin{array}{c}\text { Sangat } \\
\text { Tidak } \\
\text { setuju }\end{array}$ & $\begin{array}{l}\text { Tidak } \\
\text { setuju }\end{array}$ & setuju & $\begin{array}{l}\text { Sangat } \\
\text { Setuju }\end{array}$ \\
\hline 3. & $\begin{array}{l}\text { Informasi yang } \\
\text { ditampilkan } \\
\text { dalam aplikasi } \\
\text { Media } \\
\text { Pembelajaran } \\
\text { Berbasis } \\
\text { Augmented } \\
\text { Reality dapat } \\
\text { dipahami } \\
\text { dengan mudah } \\
\text { dan jelas } \\
\end{array}$ & 0 & $3,33 \%$ & $\begin{array}{c}50,00 \\
\%\end{array}$ & $\begin{array}{c}46,67 \\
\%\end{array}$ \\
\hline 4. & $\begin{array}{l}\text { Aplikasi Media } \\
\text { Pembelajaran } \\
\text { Berbasis } \\
\text { Augmented } \\
\text { Reality } \\
\text { memiliki } \\
\text { tampilan yang } \\
\text { menarik }\end{array}$ & 0 & $0,00 \%$ & $\begin{array}{c}10,00 \\
\%\end{array}$ & $\begin{array}{c}90,00 \\
\%\end{array}$ \\
\hline 5. & $\begin{array}{l}\text { Materi pada } \\
\text { Aplikasi Media } \\
\text { Pembelajaran } \\
\text { Berbasis } \\
\text { Augmented } \\
\text { Reality sesuai } \\
\text { dengan sub } \\
\text { tema yang ada } \\
\text { di sekolah }\end{array}$ & 0 & $0,00 \%$ & $3,33 \%$ & $\begin{array}{c}96,67 \\
\%\end{array}$ \\
\hline 6. & $\begin{array}{l}\text { Aplikasi Media } \\
\text { Pembelajaran } \\
\text { Berbasis } \\
\text { Augmented } \\
\text { Reality dapat } \\
\text { membantu } \\
\text { anak/siswa } \\
\text { dalam } \\
\text { pembelajaran }\end{array}$ & 0 & $0,00 \%$ & $6,67 \%$ & $\begin{array}{c}93,33 \\
\%\end{array}$ \\
\hline 7. & $\begin{array}{l}\text { Aplikasi Media } \\
\text { Pembelajaran } \\
\text { Berbasis } \\
\text { Augmented } \\
\text { Reality } \\
\text { menambah } \\
\text { minat belajar } \\
\text { anak }\end{array}$ & 0 & $3,33 \%$ & $\begin{array}{c}46,67 \\
\%\end{array}$ & $\begin{array}{c}50,00 \\
\%\end{array}$ \\
\hline 8. & $\begin{array}{l}\text { Aplikasi mudah } \\
\text { diinstall }\end{array}$ & 0 & $13,33 \%$ & $\begin{array}{c}53,33 \\
\% \\
\end{array}$ & $\begin{array}{c}33,33 \\
\%\end{array}$ \\
\hline 9. & $\begin{array}{l}\text { Aplikasi } \\
\text { Pembelajaran } \\
\text { aplikasi Media } \\
\text { Pembelajaran } \\
\text { Berbasis } \\
\text { Augmented } \\
\text { Reality layak } \\
\text { disebarluaskan }\end{array}$ & 0 & $0,00 \%$ & $\begin{array}{c}33,33 \\
\%\end{array}$ & $\begin{array}{c}66,67 \\
\%\end{array}$ \\
\hline 10. & $\begin{array}{l}\text { Fitur-fitur yang } \\
\text { ada pada } \\
\text { Aplikasi } \\
\text { Berjalan dengan } \\
\text { baik }\end{array}$ & 0 & $0,00 \%$ & $0,00 \%$ & $\begin{array}{c}100,00 \\
\%\end{array}$ \\
\hline
\end{tabular}

Berdasarkan hasil pada Tabel 3, Pada pernyataan "Aplikasi Media Pembelajaran Berbasis Augmented Reality ini untuk mudah digunakan", sebanyak $3,33 \%$ responden menyatakan tidak setuju. Sebanyak 13,33\% responden menyatakan setuju dan $83,33 \%$ 
menyatakan sangat setuju. Pada pernyataan "Animasi dalam aplikasi ini berjalan dengan baik.", sebanyak 33,33\% responden menyatakan setuju. 66,67\% menyatakan sangat setuju. Pada pernyataan "Informasi yang ditampilkan dalam aplikasi Media Pembelajaran Berbasis Augmented Reality dapat dipahami dengan mudah dan jelas", sebanyak 3,33\% responden menyatakan tidak setuju. Sebanyak $50 \%$ responden menyatakan setuju dan $46,67 \%$ menyatakan sangat setuju. Pada pernyataan "Aplikasi Media Pembelajaran Berbasis Augmented Reality memiliki tampilan yang menarik", sebanyak $10 \%$ responden menyatakan setuju. Sebanyak $90 \%$ menyatakan sangat setuju. Pada pernyataan "Materi pada Aplikasi Media Pembelajaran Berbasis Augmented Reality sesuai dengan sub tema yang ada di sekolah", sebanyak 3,33\% responden menyatakan setuju. Sebanyak 96,67\% menyatakan sangat setuju. Pada pernyataan "Aplikasi Media Pembelajaran Berbasis Augmented Reality dapat membantu anak/siswa dalam pembelajaran", sebanyak $6,67 \%$ responden menyatakan setuju. Sebanyak 93,33\% menyatakan sangat setuju. Pada pernyataan "Aplikasi Media Pembelajaran Berbasis Augmented Reality menambah minat belajar anak", sebanyak 3,33\% responden menyatakan tidak setuju. Sebanyak 46,67\% responden menyatakan setuju dan $50 \%$ menyatakan sangat setuju. Pada pernyataan "Aplikasi mudah diinstall”, sebanyak 13,33\% responden menyatakan tidak setuju. Sebanyak $53,33 \%$ responden menyatakan setuju dan $33,33 \%$ menyatakan sangat setuju. Pada pernyataan "Aplikasi Pembelajaran aplikasi Media Pembelajaran Berbasis Augmented Reality layak disebarluaskan", sebanyak $33,33 \%$ responden menyatakan setuju. Sebanyak $66,67 \%$ menyatakan sangat setuju. Pada pernyataan "Fitur-fitur yang ada pada Aplikasi Berjalan dengan baik", sebanyak $100 \%$ responden menyatakan sangat setuju.

Tabel 4. Hasil jawaban responden siswa

\begin{tabular}{cccccc}
\hline & & \multicolumn{4}{c}{ Jawaban Responden } \\
\cline { 3 - 6 } No & Pernyataan & $\begin{array}{l}\text { Sangat } \\
\text { Tidak } \\
\text { setuju }\end{array}$ & $\begin{array}{c}\text { Tidak } \\
\text { setuju }\end{array}$ & setuju & $\begin{array}{l}\text { Sangat } \\
\text { Setuju }\end{array}$ \\
\hline & $\begin{array}{l}\text { Saya suka } \\
\text { dengan Animasi } \\
\text { dan videonya }\end{array}$ & $0,00 \%$ & $0,00 \%$ & $33,33 \%$ & $66,67 \%$ \\
\hline 2. & $\begin{array}{l}\text { Dengan animasi } \\
\text { dan video ini }\end{array}$ & $0,00 \%$ & $0,00 \%$ & $16,67 \%$ & $83,33 \%$ \\
\hline
\end{tabular}

\begin{tabular}{|c|c|c|c|c|c|}
\hline \multirow[b]{2}{*}{ No } & \multirow[b]{2}{*}{ Pernyataan } & \multicolumn{4}{|c|}{ Jawaban Responden } \\
\hline & & $\begin{array}{l}\text { Sangat } \\
\text { Tidak } \\
\text { setuju } \\
\end{array}$ & $\begin{array}{l}\text { Tidak } \\
\text { setuju }\end{array}$ & setuju & $\begin{array}{l}\text { Sangat } \\
\text { Setuju }\end{array}$ \\
\hline & $\begin{array}{l}\text { saya jadi ingin } \\
\text { belajar lagi }\end{array}$ & & & & \\
\hline 3. & $\begin{array}{l}\text { Animasi dan } \\
\text { video dalam } \\
\text { aplikasi } \\
\text { membuat saya } \\
\text { memahami } \\
\text { pelajaran }\end{array}$ & $0,00 \%$ & $0,00 \%$ & $43,33 \%$ & $56,67 \%$ \\
\hline 4. & $\begin{array}{l}\text { suara Animasi } \\
\text { dan video jelas } \\
\text { dan bagus }\end{array}$ & $0,00 \%$ & $0,00 \%$ & $33,33 \%$ & $66,67 \%$ \\
\hline 5. & $\begin{array}{l}\text { Penjelasan ibu } \\
\text { guru mudah } \\
\text { dipahami }\end{array}$ & $0,00 \%$ & $0,00 \%$ & $50,00 \%$ & $50,00 \%$ \\
\hline
\end{tabular}

Berdasarkan Hasil pada Tabel 4, Pada pernyataan "Saya suka dengan Animasi dan videonya", sebanyak 33,33\% responden menyatakan suka. Sebanyak $66,67 \%$ menyatakan sangat suka. Pada pernyataan "Dengan animasi dan video ini saya jadi ingin belajar lagi", sebanyak $16,67 \%$ responden menyatakan suka. Sebanyak 83,33\% menyatakan sangat suka. Pada pernyataan "Animasi dan video dalam aplikasi membuat saya memahami pelajaran", sebanyak $43,33 \%$ responden menyatakan suka. Sebanyak $56,67 \%$ menyatakan sangat suka. Pada pernyataan "suara Animasi dan video jelas dan bagus", sebanyak 33,33\% responden menyatakan suka. Sebanyak $66,67 \%$ menyatakan sangat suka. Pada pernyataan "Penjelasan ibu guru mudah dipahami", sebanyak $50 \%$ responden menyatakan suka. Sebanyak $50 \%$ menyatakan sangat suka.

\section{KESIMPULAN}

Berdasarkan hasil penelitian dan pengujian, maka kesimpulan dari penelitian ini adalah Aplikasi AReP yang sudah dibangun berhasil berjalan dengan baik. Berdasarkan hasil dari pengujian usabilitas dengan kuisioner untuk wali siswa di dapatkan bahwa $93 \%$ responden sangat setuju jika AReP dapat membantu anak/ siswa dalam pembelajaran. Sedangkan hasil dari pengujian usabilitas dengan kuisioner terhadap siswa di dapatkan bahwa 83,33\% responden sangat suka jika dengan animasi dan video ini siswa jadi ingin belajar lagi. 
DAFTAR PUSTAKA

[1]

S. Arif, "2 Minggu Kasus Melonjak, Blitar Zona Merah COVID-19," sindownews, 2020.

[2] Y. Astutik, "Mendikbud: Sekolah di Zona Kuning-Merah Belajar \#dirumahaja," CNBC Indonesia, 2020.

[3] R. Akhsani, A. K. Nalendra, M. Mujiono, and I. Ismanto, "Pengukuran User Experience Pada Aplikasi Pasbhara Dengan Metode Heuristic Evaluation," Res. Comput. Inf. Syst. Technol. Manag., vol. 3, no. 1, p. 38, 2020, doi: 10.25273/research.v3i1.6247.

[4] M. Kholil, R. Akhsani, and K. Charisma, "PENGEMBANGAN GAME EDUKASI PILAH SAMPAH BERBASIS ANDROID 2 DIMENSI," JAMI J. Ahli Muda Indones., vol. 1, no. $51,2020$.

[5] S. Lukosch, M. Billinghurst, L. Alem, and K. Kiyokawa, "Collaboration in Augmented Reality," Comput. Support. Coop. Work CSCW An Int. J., vol. 24, no. 6, pp. 515-525, 2015, doi: 10.1007/s10606-015-9239-0.

[6] N. Ruswianto, R. Akhsani, D. Brigita, Y. S. Rizeky, and M. Lutfi, "Jogja Mobile Application Berbasis Augmented Reality Untuk Info Layanan Wisata Budaya," Rekayasa Teknol. Ind. dan Inf. 2016 Sekol. Tinggi Teknol. Nas. Yogyakarta, pp. 181-185, 2016.

[7] J. D. Latuheru, Media pembelajaran dalam proses belajar-mengajar masa kini. Jakarta: P2LPTK, 1988.
[8] W. Kusumah, "Pengertian media Pembelajaran." https://mediagrafika.com/pengertian-mediapembelajaran/.

[9] S. Salbino, Buku Pintar Gadget Android Untuk Pemula. Jakarta: Kunci Komunikasi, 2014.

[10] G. Kipper and J. Rampolla, Augmented Reality. 2012.

[11] DEPDIKNAS, Pedoman Umum Pengembangan Bahan Ajar Sekolah Menengah Atas. Jakarta, 2004.

[12] W. Komputer, Mudah membuat game 3 dimensi menggunaan unity $3 d$. Yogyakarta: ANDI, 2014.

[13] A. H. Sutopo, Multimedia Interaktif Dengan Flash. Yogyakarta: Graha Ilmu, 2003.

[14] A. Pramono and M. D. Setiawan, "Pemanfaatan Augmented Reality Sebagai Media Pembelajaran Pengenalan Buah-Buahan," INTENSIF J. Ilm. Penelit. dan Penerapan Teknol. Sist. Inf., vol. 3, no. 1, p. 54, 2019, doi: 10.29407/intensif.v3i1.12573.

[15] I. M. A. O. Wijaya, M. K. I Ketut Resika Arthana, S.T., and M. K. Gede Aditra Pradnyana, S.Kom., "Analisis User Experience Web Based Digital Library Jurusan Pendidikan Teknik Informatika Universitas Pendidikan Ganesha," Kumpul. Artik. Mhs. Pendidik. Tek. Inform., vol. 6, no. 2, p. 320, 2017, doi: 10.23887/karmapati.v6i2.11689. 